\title{
Diversity Status and Population Dynamics of Phytoplankton at Laxmiwadi Tank from Kolhapur District of Maharashtra, India
}

\author{
S. A. Manjare \\ Department of Zoology, Jaysingpur College, Jaysingpur
}

\begin{abstract}
The present attempt has made to study qualitative and quantitative base of phytoplankton from Laxmiwadi tank situated in the Hatkanangle tahsil of Kolhapur district, Maharashtra, India. The study revealed that total 12 species of phytoplankton resides in the tank. Out of 12 species, 5 were belonging to chlorophyceae, 4 were belonging to Bascillariophyceae and 3 were belonging to Myxophyceae. Based on the qualitative analysis, Chlorophyceae was dominant group among all. Quantitative analysis of phytoplankton showed monthly variation in the total number of organisms. However, the highest number was noted during the months of winter season while lowest during monsoon season. The percent composition of phytoplankton revealed that Chlorophyceae members were dominant over both the years.
\end{abstract}

Keywords: Phytoplankton, diversity, population dynamics, Laxmiwadi, freshwater tank.

\section{Introduction}

Freshwater tanks, reservoirs, lakes, etc. have characterized by the presence of phytoplankton as producer organisms, without which the ecosystem is considered to be incomplete. These freshwater bodies are regarded as life supporting systems for millions of organisms. Among which phytoplankton are microscopic organisms only those prepare their own food. Population dynamics of this phytoplankton get influenced by many physico-chemical parameters of water. Now-a-days, anthropogenic activities exerting a great pressure on these freshwater sources to fulfill the need of water for drinking, agricultural and industrial use. Indeed, these water reservoirs become the site of drainage and sewage release, due to which physical and chemical parameters get altered, ultimately leading to decline in the floral and faunal diversity. Phytoplankton is an important base of freshwater ecosystem and also performs a major role in the production of organic matter. The presence of phytoplankton in any water body can lead to productive and sustainability of that water body. The assemblage in the form of composition and distribution is dependent on the physical, chemical and biological properties of water (Patil et al., 2015). Plankton is the most sensitive floating community which is being the first target of water pollution, thus any undesirable change in aquatic ecosystem affects diversity as well as biomass of this community. Phytoplankton are Autotrophs and belonging to first trophic level (Mondal et al., 2014). Various workers made an attempt to study the planktonic diversity over this area are Bhosale et al. (2010 a) and Bhosale et al. (2010 b). Present attempt was made to know the phytoplankton diversity from Tamadalge freshwater tank.

\section{Materials and Methods}

\section{Study Area}

Laxmiwadi tank was constructed in the year 1977-78 by Zilla Parishad. It is situated in the vicinity of Hatkanangle
Tahsil of Kolhapur district. It is about $7 \mathrm{~km}$ away from Hatkanangle, towards west side. It covers an area of about 102 ha with an average water spread area, of about 10.6 ha. It is basically used as a source of drinking water and for domestic purpose, it exhibit fluctuating trend in its water level. Laxmiwadi tank was characterized by absence of littoral and submerged vegetation. The water level declines and characterized by anthropogenic activities and absence of molluscan fauna. For fishery purpose, it was auctioned on lease for the period of three years to the local fishermen community.

\section{Phytoplankton Analysis}

Present investigation is made between January 2011 and December 2012. The plankton samples were collected from tank monthly by using plankton net having mesh size of $50 \mu$. The 100 liter water sample was filtered through the plankton net in $100 \mathrm{ml}$ sampling bottle attached to the plankton net. The collected plankton sample was preserved in $4 \%$ formalin. The qualitative and quantitative analysis of Phytoplankton was carried out in the laboratory with the help of Sedgwick- Rafter cell counting chamber. The samples were kept for setting for a period of $48 \mathrm{hrs}$. The phytoplankton were identified as described by Needham and Needham (1962), Adoni et al. (1985), Michael (1984), Tonapi (1980), Trivedy and Goel (1987).

\section{Result and Discussion}

The seasonal variations in phytoplankton density were observed as maximum in winter season and minimum in monsoon. Comparatively, higher density of phytoplankton was recorded in winter and summer than the monsoon season. The qualitative analysis of phytoplankton belonging to four major groups such as Chlorophyceae, Bascillariophyceae and Myxophyceae were identified.

Total thirteen species of phytoplankton, belonging to four orders and five families were recorded. During the study period 5 Chlorophyceae members, 4 members were 


\section{International Journal of Science and Research (IJSR) \\ ISSN (Online): 2319-7064 \\ Index Copernicus Value (2013): 6.14 | Impact Factor (2014): 5.611}

belonging to Bascillariophyceae, 3 species were Myxophyceae and one species was of Dinophyceae. The Chlorophyceae member includes Spirogyra, Hydrodyctyon, Oedogonium, Pediastrum and Ankistrodesmus. The Bascillariophyceae comprises Coscinodiscus sp., Navicula, Cyclotella and Surirella, among these former three were noted dominant. The Myxophyceae members were represented by Nostoc, Anabaena, and Microcystis. Among these Nostoc and Anabaena were observed as abundant in the plankton samples of these tanks.

The quantitative results for total number of phytoplankton during the year 2011 and 2012 are given in Figure 1. The total phytoplankton during 2011 were fluctuated from 1110 Unit/ml to $3150 \mathrm{Unit} / \mathrm{ml}$. The numbers of planktons were lower in the month of July while higher in the month of March. The total number of planktons during 2012 were ranged between 770 Units $/ \mathrm{ml}$ and 3813 Units $/ \mathrm{ml}$. There was decline in number of phytoplankton in the month of July while incline in the month of March. The study revealed that the total number of phytoplankton were declined in the months of monsoon due to increased water level and decreased transparency. Low light may also be another cause for the decrease in the level of planktons during monsoon season. There was incline in the number of phytoplankton during the months of summer season might be due to clear water transparency, intense sunlight and increased light penetration.

Monthly variation of plankton with reference to classes is noted in the Figure 2 and Figure 3. The numbers of Chlorophyceae members were fluctuated from 363 Units/ml to 1575 Units/ml during the year 2011 while during 2012, members of Chlorophyceae were fluctuated from 292 Units/ml to 1810 Units $/ \mathrm{ml}$. There was decline of Chlorophyceae members in the month of August during both the years while the maximum Chlorophyceae members were noted in the month of February and January during the year 2011 and 2012 respectively.

Monthly variation of plankton with reference to classes in noted in the Figure 2 and Figure 3. The numbers of Bascillarophyceae members were fluctuated from 0 Units $/ \mathrm{ml}$ to 967 Units/ml during the year 2011 while during 2012, members of Bascillarophyceae were fluctuated from 0 Units/ml to 1072 Units $/ \mathrm{ml}$. There was decline of Bascillarophyceae members in the month of August and July-August during 2011 and 2012 respectively while the maximum Bascillarophyceae members were noted in the month of February during both the years.

Monthly variation of plankton with reference to classes is noted in the Figure 2 and Figure 3. The numbers of Myxophyceae members were fluctuated from 0 Units $/ \mathrm{ml}$ to 876 Units/ml during the year 2011 while during 2012, members of Myxophyceae were fluctuated from 0 Units $/ \mathrm{ml}$ to 1235 Units $/ \mathrm{ml}$. There was decrease of Myxophyceae members in the month of December during both the years while the maximum Myxophyceae members were noted in the month of July during both the years.

The total composition of planktons includes the members of Chlorophyceae, Bascillarophyceae and Myxophyceae. The total composition of the planktons (Figure 2 and 3 ) revealed that Chlorophyceae was noted dominant during both the years with holding percentage of $44.64 \%$ and $45 \%$ during 2011 and 2012 respectively. The Bascillarophyceae was followed by Chlorophyceae and the total composition of this group indicated by $28.92 \%$ and $29.50 \%$ during 2011 and 2012 respectively. The percent composition of Myxophyceae in lower among other groups and it holds $26.42 \%$ during the year 2011 and $25.48 \%$ during the year 2012.

Anitha and Singara found phytoplanktons belonging from classes Chlorophyceae, Bacillariophyceae, Cyanophyceae and Euglenophyceae during July 1999 to June 2001 from Lower Manar Dam and Kakatiya canal, Karimnagar, Andhra Pradesh, India.

The population condition was stable during the months of April and May. The density slowly declined during June and the lowest value was observed during the month of July 2011 and 2012. In the present study, the phytoplankton production was coinciding with the optimum water depth of $1 \mathrm{~m}$. This is an agreement with the earlier works of Sukumaran and Das (2001) in some freshwater reservoir of Karnataka. During the study Bacsillariophyceae, Chlorophyceae and Myxophyceae were most dominated in summer and minimum observed in rainy season. Devika et $a l$. , (2006) also recorded high population during summer and suggested that this might be due to physical rather than chemical condition in which the water temperature and transparency had a direct relation with phytoplankton population. Ven Den Hoeck et al., (1995) reported that higher Chlorophyceae are a large and important group of fish water algae. \%). Chlorophyceae was observed to be the most dominant class of phytoplankton. Thus qualitatively Chlorophyceae formed the largest group and was followed by other group.

\section{Conclusion}

The present study can be concluded that the qualitative status of phytoplankton was moderate rich while the quantitatively it is rich with Chlorophyceae as dominant group. Seasonal variations in total number of planktons were noted and found that the winter season was favourable season for the growth and development of phytoplankton.

\section{References}

[1] Anitha U. Devi and Singara M.A. Charya, Phytoplankton in Lower Manar Dam and Kakatiya Canal, Karimnagar, Andhra Pradesh, Nat. Environ. Pol. Technol., 6(4), 643-648, (2007).

[2] Bhosale Leela J., S. M. Patil, Surekha N. Dhumal and S. S. Sathe (2010 a). Occurrence of phytoplankton in the water bodies of MirajTaluka of Maharashtra. The Ecoscan. 4(1): 73-76.

[3] Leela J. Bhosale, Surekha N. Dhumal and Anjali B. Sabale $(2010$ b). Phytoplankton diversity of in four lakes of Satara District, Maharashtra state. The Ecoscan. 5(3): 449-454.

[4] Sachinkumar R. Patil, S.S. Patil and T. V. Sathe (2015). Occurrence of phytoplankton in major freshwater bodies of Ajara tahsil, Kolhapur district (MS), India.

\section{Volume 4 Issue 11, November 2015}




\section{International Journal of Science and Research (IJSR) \\ ISSN (Online): 2319-7064}

Index Copernicus Value (2013): 6.14 | Impact Factor (2014): 5.611

Asian Academic Research Journal of Multidisciplinary, 1 (31): 35-45.

[5] Sukumaran, P.K. and A.K. Das: Distribution of plankton in some freshwater reservoirs of Karnataka. J. Inland. Fish. Soc. India, 33, 29-36 (2001).

[6] Needham, J. G. and Needham, P. R. (1962). A guide to freshwater biology. Holden Day Ins., San Francisco (USA). PP. 108.

[7] Adoni, A. D., Gulwant, J, Chourasia,S. K., Vaidya,A.K., Yadav,M. and Verma ,H.G.(1985). Work book of Limnology, Prabha Publishers, C-10, Gour Nagar, Sagar (India).
[8] Michael, R. G. (1984). Ecological methods for laboratory and field investigations. Tata McGraw Hill publishing Company Ltd. New Delhi. PP. 4-11.

[9] Tonapi, G. T. (1980). Freshwater animals of India an ecological approach. Oxford and IBH Publishing Company, New Delhi. PP 314-315.

[10] Trivedy, R. K., Goel, P. K. and Trisal, C. L. (1987). Practical methods in Ecology and Environmental Science.

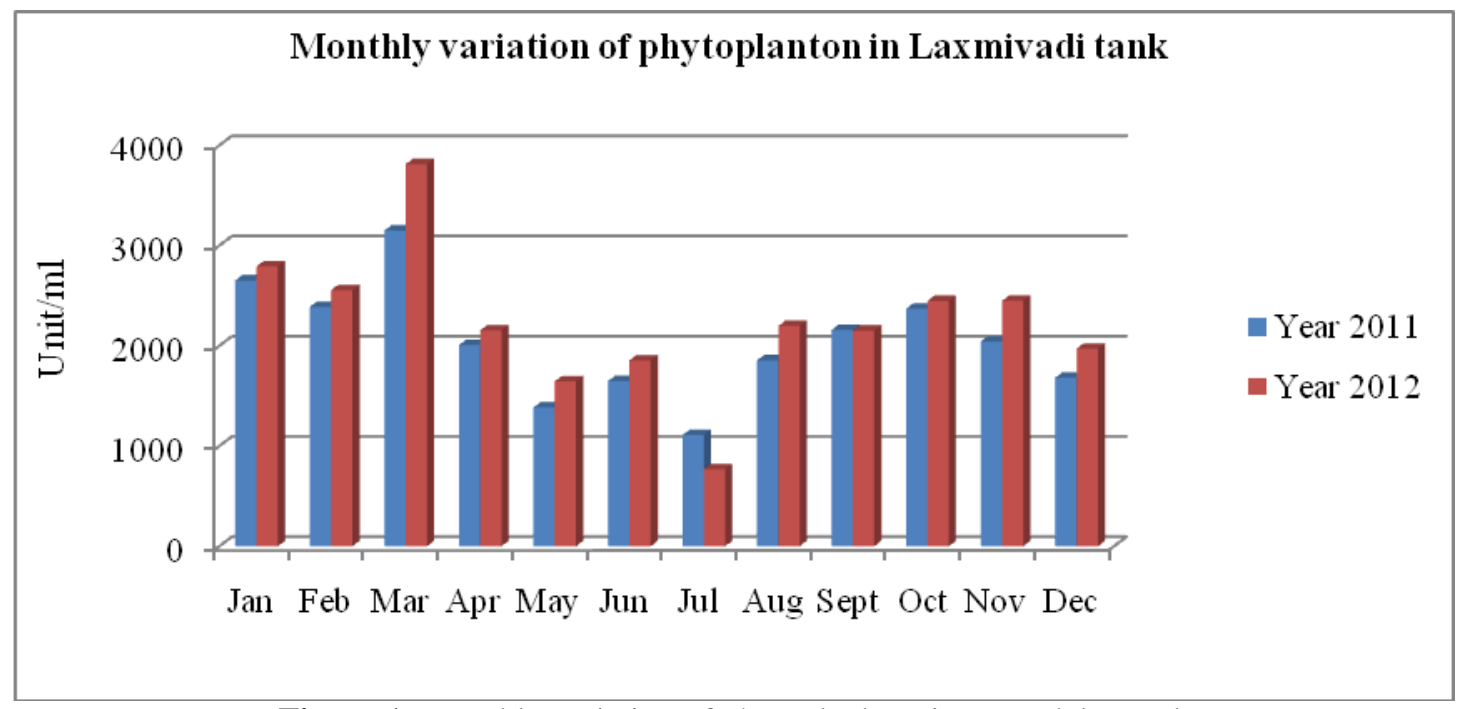

Figure 1: Monthly variation of phytoplankton in Tamadalge tank

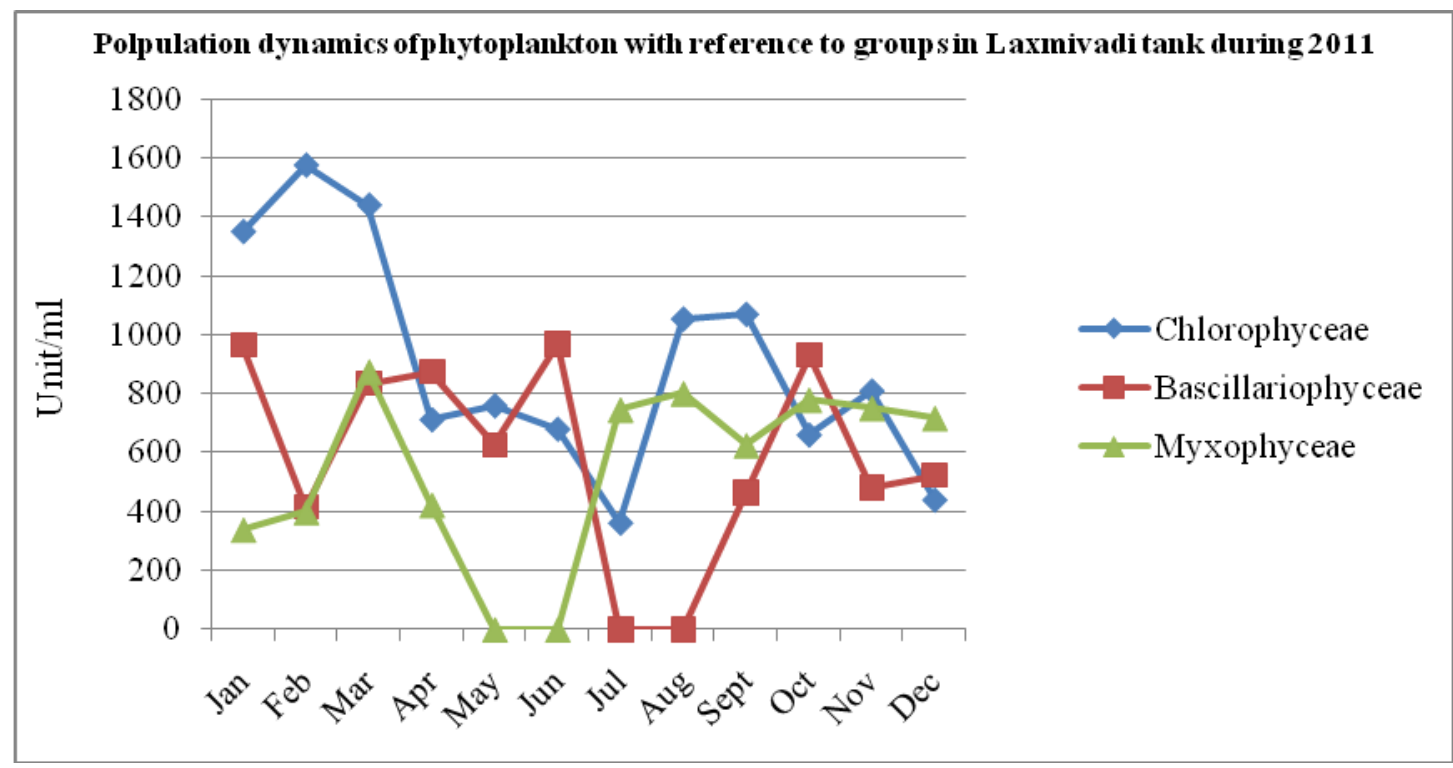

Figure 2: Population dynamics of phytoplankton with reference to groups in Tamadalge tank during 2011 
International Journal of Science and Research (IJSR)

ISSN (Online): 2319-7064

Index Copernicus Value (2013): 6.14 | Impact Factor (2014): 5.611

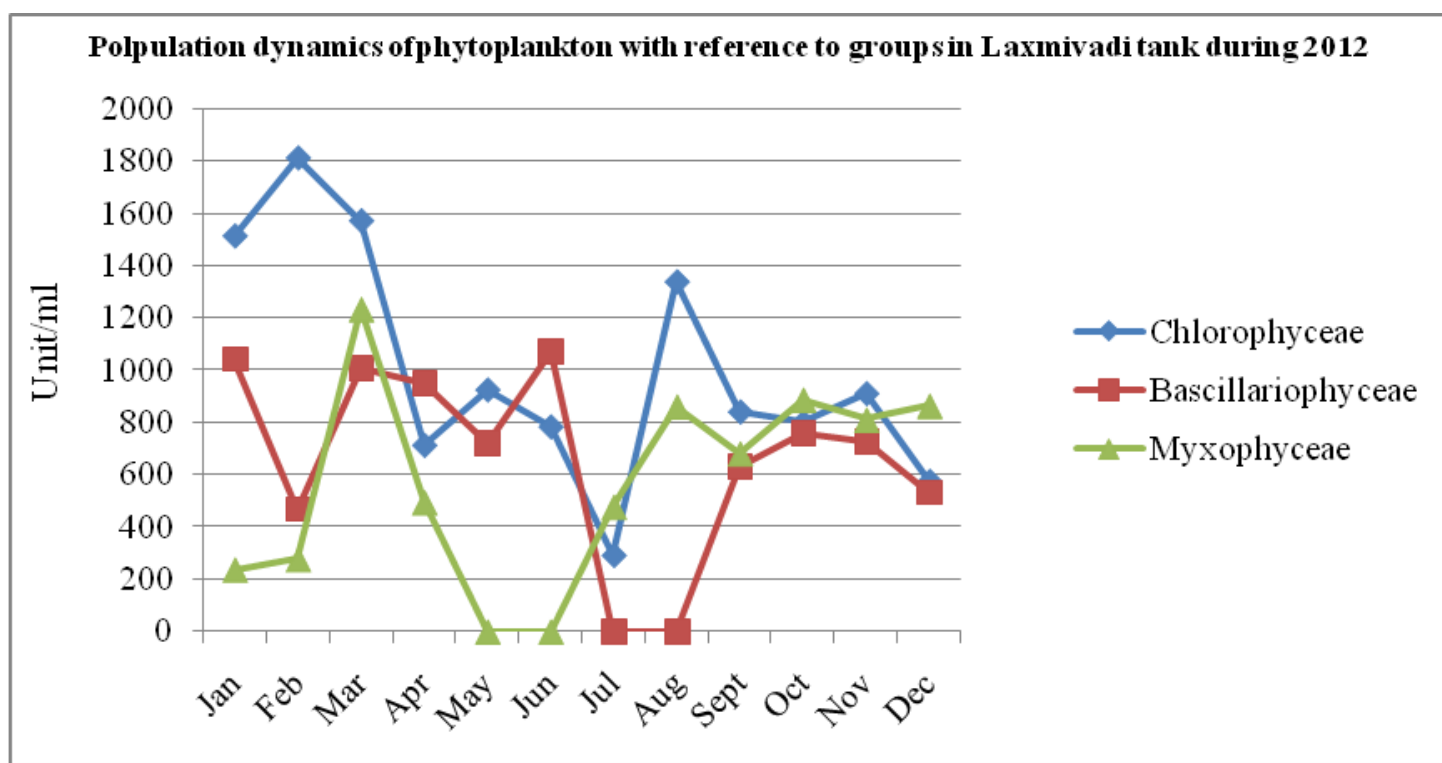

Figure 3: Population dynamics of phytoplankton with reference to groups in Tamadalge tank during 2012

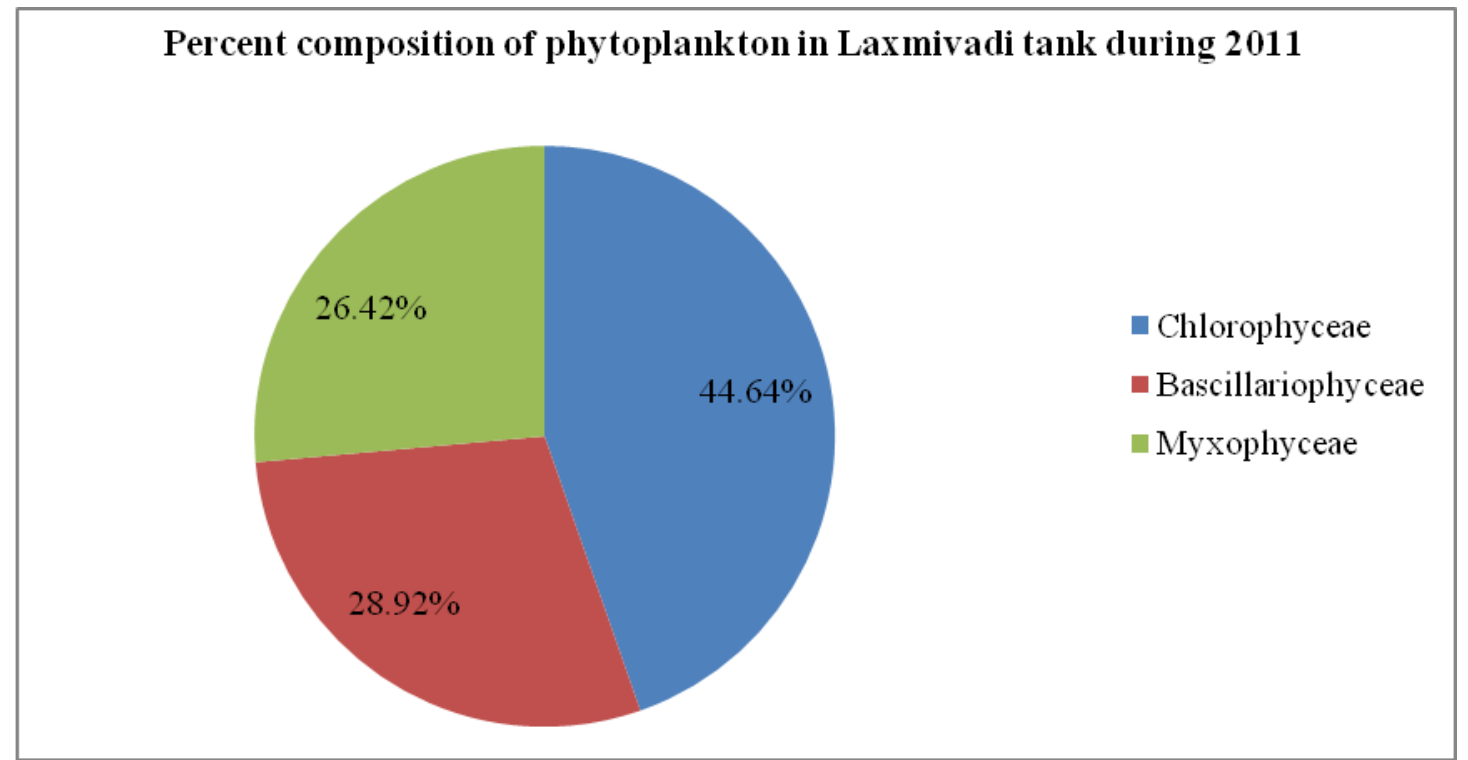

Figure 4: Percent composition of phytoplankton in Tamadalge tank during 2011

Percent composition of phytoplankton in Laxmivadi tank during 2012

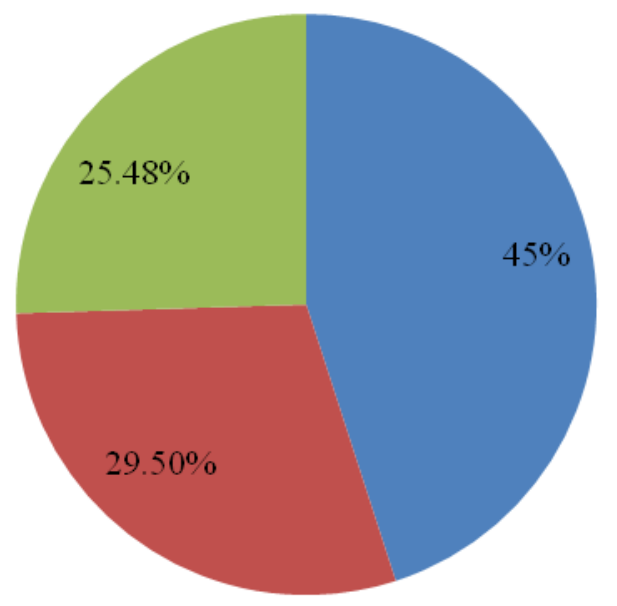

- Chlorophyceae

- Bascillariophyceae

- Myxophyceae

Figure 5: Percent composition of phytoplankton in Tamadalge tank during 2012

\section{Volume 4 Issue 11, November 2015}

www.ijsr.net 